\title{
Technical and Economic Analysis of a Hybrid Generation System of Wind Turbines, Photovoltaic Modules and a Fuel Cell
}

\author{
Radosław Szczerbowski ${ }^{1, a}$ and Bartosz Ceran ${ }^{1}$ \\ ${ }^{1}$ Poznan University of Technology, Poznań, Poland
}

\begin{abstract}
The paper presents the results of the analysis of the economic and manufacturing system consisting of wind turbines, photovoltaic modules, polymer membrane fuel cell and the electrolyzer. The system supplies the customer profile at the assumed wind and solar conditions. Energy analysis was conducted on the basis of the balance equations produced and received electric power. To assess the economic efficiency of investments adopted the following economic indicators: NPV, IRR, MIRR, MNPV, DPP. The authors describe the limits of investment costs intended for the construction, which use hybrid power generation system (HPGS) is viable.
\end{abstract}

\section{Introduction}

The rapid development of renewable energy sources and distributed generation makes the electrification system will be changed to the form in which the road transit of electricity will be the shortest possible. A very promising group of distributed energy sources are sources that use renewable energy resources, especially the Sun and the wind. The primary disadvantage of these sources is a strong dependence of the amount of energy produced from the current weather conditions. As a result, forecasting the production of electricity is very difficult.

Way of efficient use of renewable and distributed energy resources the original hybrid power generation systems are, or combinations of connections renewable and conventional sources (small gas turbines, generators, powered by engines, fuel cells, etc.) and/or energy storage (flywheel, batteries, electrolyzers with hydrogen tanks, supercapacitors, etc.). Of these energy storage technology shows potential PEMFC type fuel cell in conjunction with electrolyzers with hydrogen tanks. This system is characterized by a high density of energy stored volume larger than a $500 \mathrm{Wh} / \mathrm{kg}$. The integration of the different technologies in electricity generation in such systems allows the fuller satisfaction of energy needs. In addition, the cooperation of solar power plants and wind farms with storage systems definitely improve their work [1,2]

Storage systems are able to store surplus generated by power plants, energy and power energy stored receivers when the plant is not able to cover the needs of the recipient. This allows to significantly improvethe availability of photovoltaic power plants and wind farms. In addition, the construction of hybrid manufacturing systems that use renewable and distributed energy resources, will help reduce the cost of electricity. This is the reason that these sources are located close to the energy consumers.

Hybrid power generation systems are also of great importance for the protection of the environment. Used in these systems of renewable generation does not emit pollutants.

The concept of a hybrid system is defined, inter alia, in the regulation of the Minister of economy of 18 October 2012 in the document filed, that the hybrid is a unit of generation which produces electricity, or electricity and heat. In the process of generating electricity or heat energy carriers are produced separately in renewable energy sources. There is also the possibility of using the auxiliary fuel to produce electricity or heat.

It seems reasonable to hybrid power generation systems used in areas distant from the traditional sources of energy, or in the case when there are difficulties with fuel to conventional generating units. Hybrid power generation systems most often are made of two or more sources. Build them that way so that you can offset the advantages and disadvantages of individual sources. This fact makes these systems belong to the very expensive due to the need for the use of renewable energy sources and energy storage systems [3].

\section{Hybrid generation system}

The excess energy produced from renewable sources is used for electrolysis process (decomposition of water into hydrogen and oxygen). Hydrogen is compressed and stored, and then used in a fuel cell to produce electricity, at a time when it is needed by customer. The use of electrolysis process of energy produced

\footnotetext{
${ }^{\mathrm{a}}$ Corresponding author: radoslaw.szczerbowski@put.poznan.pl
} 
by renewable means that operation of the hybrid system is emission-free. The purchase of an additional backup purposes, hydrogen may be charged a small emissions associated with its production, depending on the technology used $[4,5]$.

Hybrid power generation system flowsheet analysis is shown in Figure 1.

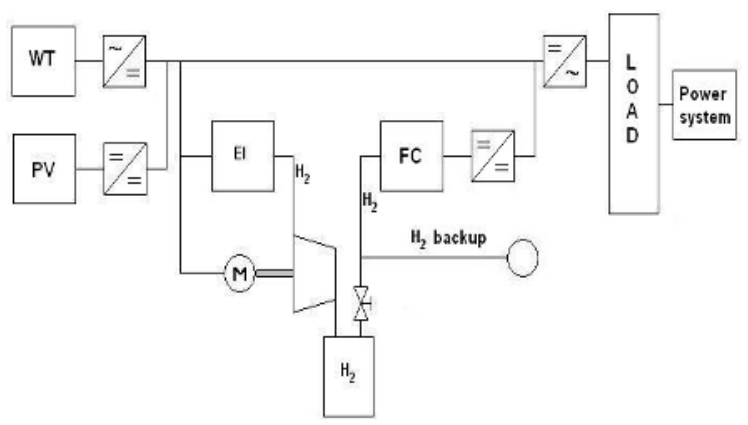

Figure 1. Flowchart-hybrid power generation system (own study)

To analyze the work of the hybrid power generation system consisting of wind turbines, photovoltaic modules, polymer membrane fuel cell and the electrolyzer assumes the customer profile of municipal (Fig. 2) with a maximum power $56 \mathrm{~kW}$ during the winter season, $48 \mathrm{~kW}$ in the spring-autumn season and $40 \mathrm{~kW}$ during the summer and the annual demand for electricity in the amount of $286.9 \mathrm{MWh}$.

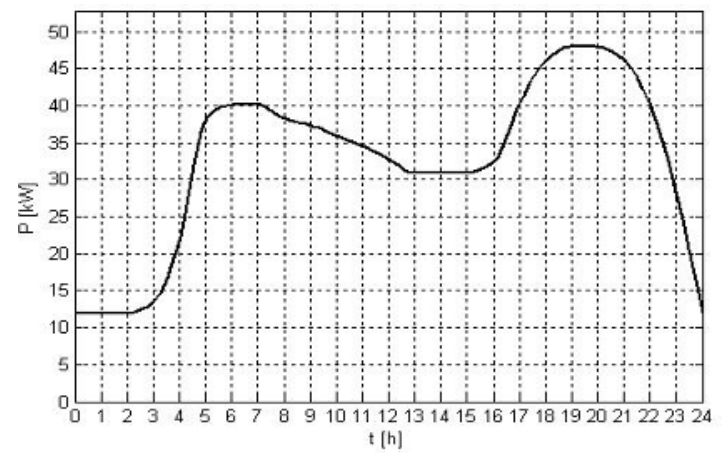

Figure 2. Energy demand profile recipient of municipal - winter season (own study)

In figures 3 and 4 shows the annual timetables sunlight and wind speed technical-economic analysis be adopted.

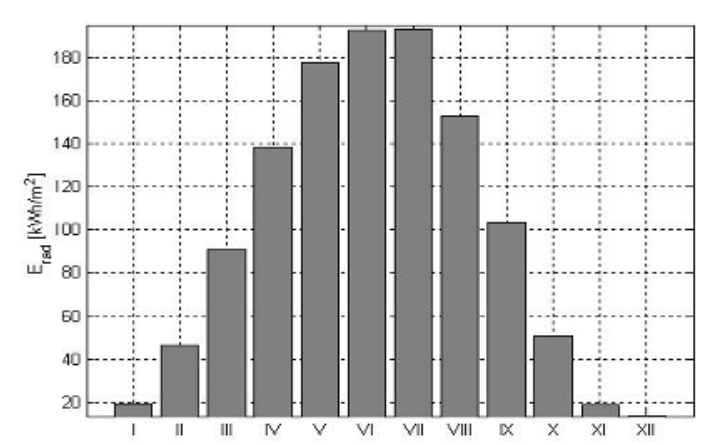

Figure 3. The annual distribution of sunlight (own study)

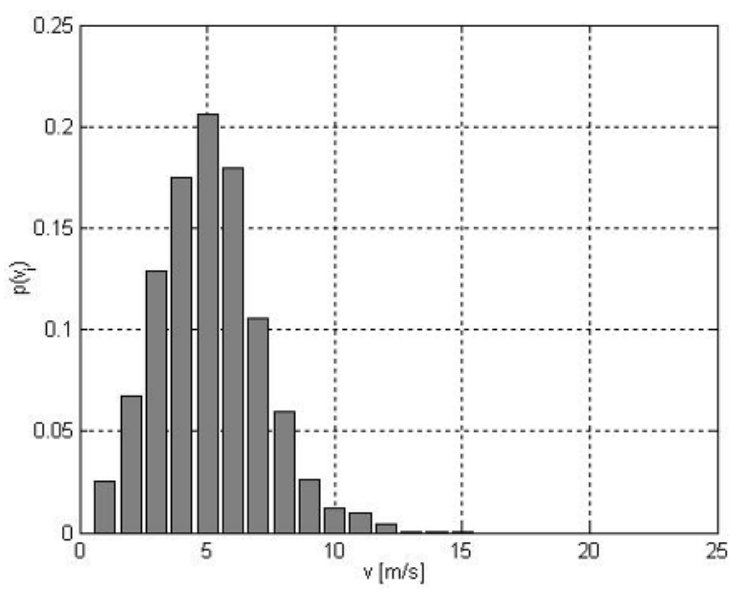

Figure 4. The annual distribution of wind speeds (own study)

\subsection{Selection of the composition of the generating units of hybrid power generation system}

With a view to the selection of the composition of the generating units to meet the needs of the customer, the following equation can be used [6]:

$$
\begin{gathered}
\Delta P=P_{a v_{-} \text {gen }}-P_{a v_{-} \text {load }} \rightarrow \mathrm{min} \\
P_{a v_{-} \text {gen }}=n_{c f_{-} P V} \cdot P_{P V}+n_{c f_{-} W T} \cdot P_{W T} \\
n_{c f_{-} P V}=\frac{P_{a v_{-} P V}}{P_{P V}} \\
n_{c f_{-} W T}=\frac{P_{a v_{-} W T}}{P_{W T}}
\end{gathered}
$$

where: $P_{a v \_g e n}-$ mean value of power generated by renewable sources, $P_{a v}$ load - average input power by the recipient, $\mathrm{n}_{\mathrm{cf}}-\mathrm{a}$ capacity factor of each renewable energy sources, $\mathrm{P}_{\mathrm{PV}}$ - rated power of photovoltaic installation, $\mathrm{P}_{\mathrm{WT}}-$ rated power of wind turbine.

The value under the average for the period $\mathrm{T}$ is designated with the dependencies:

$$
\begin{gathered}
P_{a v_{-} P V}=\frac{A_{P V}}{T_{a}} \\
A_{P V}=W_{k} \cdot W_{w} \cdot \int_{0}^{T} P_{a v_{-} P V} d t
\end{gathered}
$$

where: $A_{P V}$ - electricity produced by photovoltaic system at time $\mathrm{T}, \mathrm{W}_{\mathrm{k}}-\mathrm{a}$ correction factor that takes into account the angle of installation referral to the South and the angle of deviation of the modules from the level, $\mathrm{W}_{\mathrm{w}}$ - the coefficient of performance.

For the determination of the amount of electricity produced by photovoltaic modules uses the characteristics of the $P_{P V}=f(E)$ developed on the basis of external characteristics family $U=f(I)$ (Fig. 5). Photovoltaic modules system is equipped with an MPPT maximum power point tracking $\left(\mathrm{P}_{\mathrm{PV}}=\mathrm{P}_{\mathrm{MPP}}\right)$. 


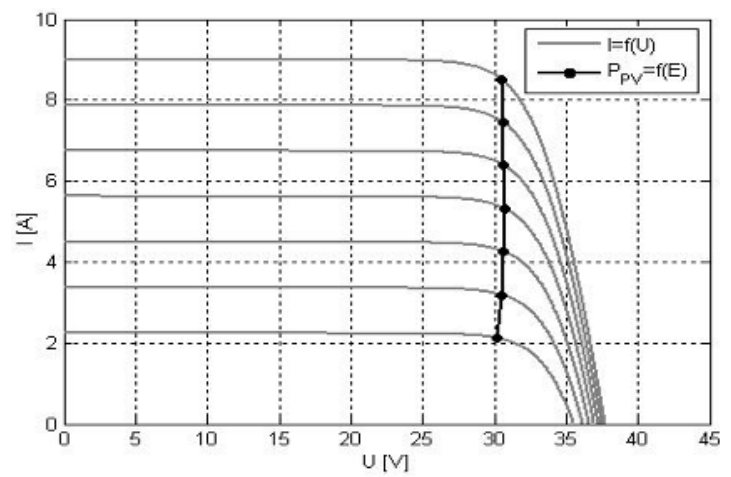

Figure 5. External characteristics of PV module family (own study)

In order to determine the average power produced by wind turbines was operational characteristics $\mathrm{P}=\mathrm{f}(\mathrm{v})$ and the distribution of wind speeds (eq. 7) presented in the form of a continuous function $f(v)$ using the Weibull distribution [7].

$$
f(v)=\frac{k}{\lambda}\left(\frac{v}{\lambda}\right)^{k-1} e^{-(v / \lambda)^{k}}
$$

where: $\mathrm{v}$ - wind speed $[\mathrm{m} / \mathrm{s}], \mathrm{k}$ - shape parameter $(\mathrm{k}>0)$, $\lambda$ - the scale parameter $(\lambda>1)$,

$$
P_{a v_{-} W T}=\int_{0}^{\infty} P(v) f(v) d v
$$

A graphical interpretation of the determination of the average power is shown in Figure 6.

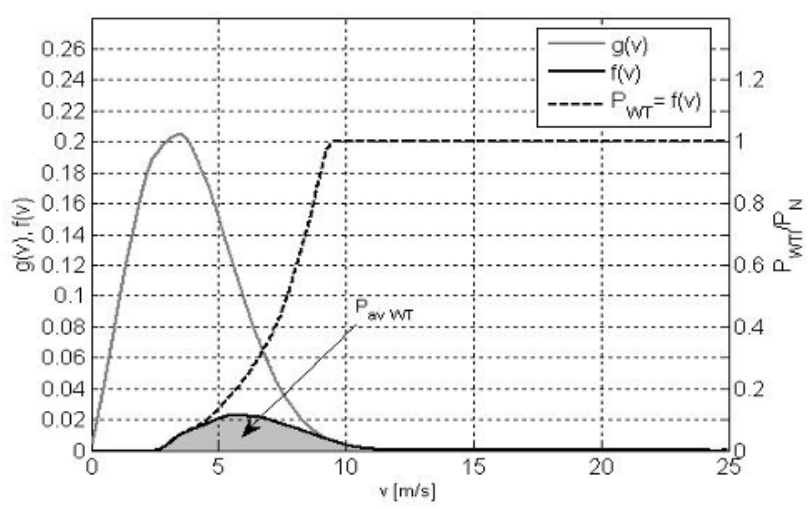

Figure 6. Determination of annual average wind power capacity (own study)

For the customer profile to be analyzed on the basis of equations (1-8) 3 proposed wind turbines with a capacity of $50 \mathrm{~kW}$, photovoltaic installation consisting of 330 modules with a capacity of $250 \mathrm{~W}$ each.

\subsection{The energy performance of energy storage}

Energy storage has been selected based on the following assumptions [6]:

- fuel cell is able to meet the instantaneous maximum demand:

$$
P_{F C}=P_{\text {max } \_ \text {load }}
$$

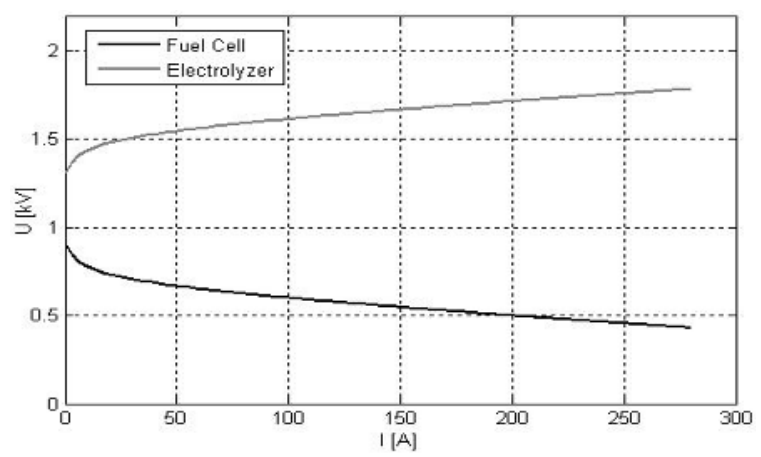

Figure 7. The characteristics of $U=f(I)$ fuel cells and the cell (own study)

- electrolyzer is able to accept temporary power generated by photovoltaic system and wind sources:

$$
P_{E l}=k \cdot\left(P_{\max _{-} W T}+P_{\max _{-} P V}-P_{\min _{-} \text {load }}\right)
$$

where: $\mathrm{P}_{\mathrm{EL}}-$ rated power of electrolyzer, $\mathrm{P}_{\text {max_WT }}-$ the maximum instantaneous wind turbines, $\mathrm{P}_{\text {max_PV }}$ - instantaneous maximum power photovoltaic installation, $\mathrm{P}_{\text {min_load }}-$ minimum instantaneous customer demand, $\mathrm{k}$ - coefficient simultaneity of maximum power generation by photovoltaic system and wind sources.

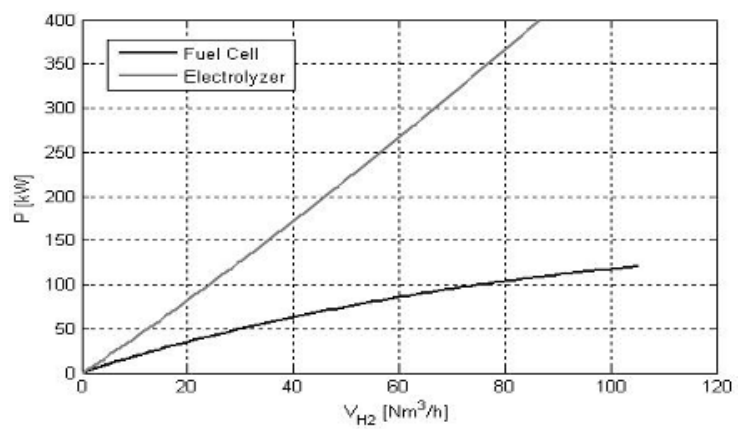

Figure 8. The characteristics of the $\mathrm{P}=\mathrm{f}\left(\mathrm{V}_{\mathrm{H}}\right)$ fuel cells and the cell (own study)

To determine the amount of the hydrogen produced by the electrolyzer and the quantities consumed by the hydrogen fuel cell used characteristics $V_{\mathrm{H} 2}=\mathrm{f}(\mathrm{P})$ developed on the basis of external characteristics of the fuel cell and electrolyzer $U=f(I)$.

Examples of external characteristics of the pile with a capacity of $50 \mathrm{~kW}$ shown in Figure 7 and Figure 8.

The main energy store's own needs device consisting of a set of electrolyzer - fuel cell is compressor. The power needed for its supply is described by the formula:

$$
P_{\text {comp }}=m_{H_{2}} \frac{\kappa}{\kappa-1} p_{0} v_{0}\left[\left(\frac{p_{1}}{p_{0}}\right)^{\frac{\kappa-1}{\kappa}}-1\right] \frac{1}{\eta_{i}}
$$

where: $\mathrm{m}_{\mathrm{H} 2}[\mathrm{~kg} / \mathrm{s}]$ - the mass flow of hydrogen, $\kappa$ - the exponent of the emagram $(\kappa=1.41$ for hydrogen $)$, $\mathrm{p}_{0}[\mathrm{MPa}]$ - hydrogen pressure before compression, $\mathrm{v}_{0}\left[\mathrm{~m}^{3} / \mathrm{kg}\right]$ - an appropriate volume of hydrogen, 
$\mathrm{p}_{1}[\mathrm{MPa}]$ - hydrogen pressure after compression, $\eta_{i}-$ compressor internal efficiency

The relationship required work the compressor pressure function is shown in Figure 9.

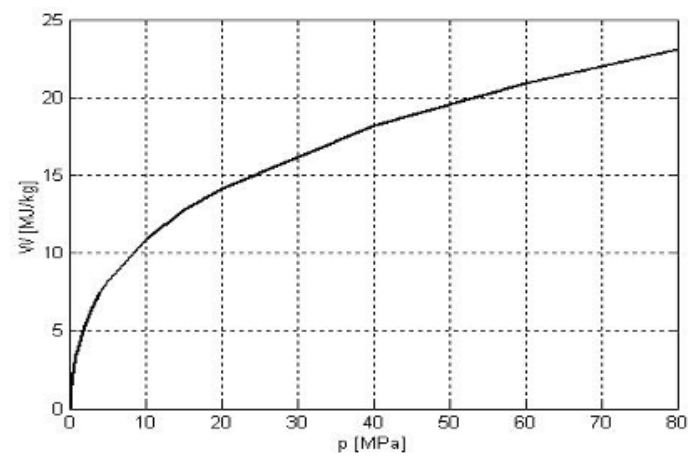

Figure 9. The work of the compressor as a function of the compression pressure (own study)

In the present case, the proposed fuel cell stack with a nominal power of $50 \mathrm{~kW}$, and the electrolyzer with a capacity of $200 \mathrm{~kW}$.

\section{Energy analysis of hybrid power generation system}

Energy analysis was conducted on the basis of the balance equations produced and received electricity power from hybrid power generation system. The balance of power in the system, depends on the ratio of power generated by RES sources to the demand of the recipient. In the case where the demand is less than the power generated balance sheet equation takes the form $[1,6]$ :

$$
P_{\text {load }}=P_{P V}+P_{W T}-P_{E l}-P_{\text {comp }}
$$

If the demand exceeds the power produced by sources the receiver power describes the formula:

$$
P_{\text {load }}=P_{P V}+P_{W T}+P_{F C}
$$

In Figure 9 illustrates parsed the energy profile of the recipient and the production of electricity by RES sources on the selected date.

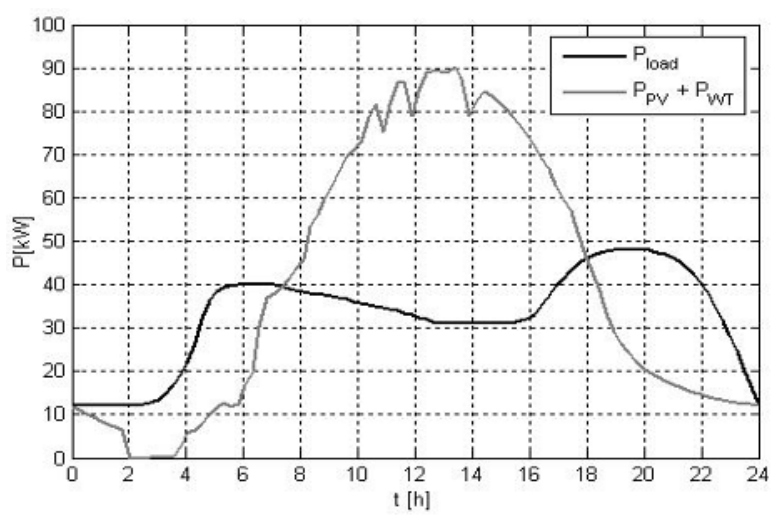

Figure 10. The energy profile of the recipient and the power produced by wind and photovoltaic on the selected day (own study)
In a substantial part of the day (in the present case), the weather conditions do not allow the manufacturing of such quantity of energy that equates demand of the customer. In $\mathrm{h}$. 0-7 and 18-24 missing energy provides a stack of fuel cells. In $h$. 7-18 working electrolyzer energy in the form of surplus storage of hydrogen (Fig. 10).

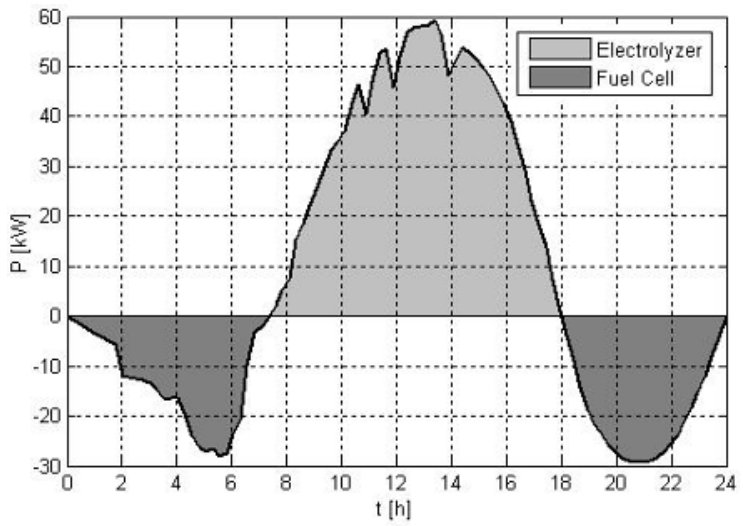

Figure 11. Fuel cells work period and the cell (own study)

Hydrogen is supplied in the first place from the electrolyzer. In the case of the total consumption of hydrogen in the tank, the fuel cell is powered by the backup. When carrying out calculations for the given profiles of sunlight and wind conditions on an annual basis the following results were obtained:

- the volume of hydrogen produced in the process of electrolysis $50481 \mathrm{Nm}^{3}$,

- annual consumption of hydrogen fuel cell stack $124560 \mathrm{Nm}^{3}$ hydrogen,

- with the "backup" $74079 \mathrm{Nm}^{3}$.

The results obtained on the basis of an analysis of energy efficiency form the basis to conduct the economic analysis with that of the hybrid system.

\section{Economic analysis of hybrid power generation system}

An assessment of the economic efficiency of investment in the energy sector is based on the following economic indicators:

- Net Present Value - NPV:

$$
N P V=\sum_{k=1}^{N} P V_{d, k} \times C F_{k}-C F_{0}
$$

where: $\mathrm{CF}_{\mathrm{k}}$ - positive net cash flows, $\mathrm{CF}_{0}-$ investment costs, $\quad \mathrm{PV}_{\mathrm{d}, \mathrm{k}}-$ the $\mathrm{k}$-factor of discounting at the discount rate (d) k-this period

- Modified Net Present Value - MNPV:

$$
M N P V=P V_{d, N} \sum_{k=1}^{N} F V_{r, N-k} \times C F_{k}-C F_{0}(15)
$$

where: $\mathrm{FV}_{\mathrm{r}, \mathrm{N}-\mathrm{k}}-$ coefficient of capitalizing on the reinvestment rate ( $\mathrm{r}$ ) and $\mathrm{N}-\mathrm{k}$ during this 
period, $\mathrm{N}$ - the total duration of the investment project.

- Profitability Index - PI:

$$
P I=\frac{\sum_{k=1}^{N} P V_{d, k} \times C F_{k}}{C F_{0}}
$$

- Internal Rate of Return - IRR:

$$
\sum_{k=1}^{N} P V_{I R R, k} \times C F_{k}=C F_{0}
$$

where: $P V_{\text {IRR,k }}$ - discount factor at a discount rate equal to the internal rate of return (IRR) and the k-th period,

- Modified Internal Rate of Return - MIRR:

$$
M I R R=\sqrt{\frac{\sum_{k=1}^{N} F V_{r, N-k} \times C F_{k}}{C F_{0}}}-1
$$

where: $\mathrm{FV}_{\mathrm{r}, \mathrm{N}-\mathrm{k}}-$ coefficient of capitalizing on the reinvestment rate (r) and N-k during this period, $\mathrm{N}$ - the total duration of the investment project,

- Discount Payback Period - DPP:

$$
\sum_{k=1}^{n=D P P} P V_{d, k} \times C F_{k}=C F_{0}
$$

For the purpose of the economic analysis with that of the adopted investment listed in Table 1. Variant I contains the current value of the investment of the hybrid power generation system devices. Variant II contains the expected investment of equipment per year by 2050 [8- 19].

Table 1. Investment costs

\begin{tabular}{|c|c|c|}
\hline Unit & $\begin{array}{c}\text { Variant I } \\
\text { [thousand } \\
\text { PLN] }\end{array}$ & $\begin{array}{c}\text { Variant II } \\
\text { [thousand } \\
\text { PLN] }\end{array}$ \\
\hline Wind turbine $50 \mathrm{~kW}$ & $\mathbf{3 0 0}$ & $\mathbf{2 5 0}$ \\
\hline PV installation $82,5 \mathrm{~kW}$ & $\mathbf{5 0 0}$ & $\mathbf{3 6 0}$ \\
\hline $\begin{array}{c}\text { Fuel cell } 50 \mathrm{~kW} \\
\text { kW, compressor, the hydrogen } \\
\text { tank) }\end{array}$ & $\mathbf{5 1 6}$ & $\mathbf{3 1 6}$ \\
\hline $\begin{array}{c}\text { Energy storage (electrolyzer } 130 \\
\text { the cost of hydrogen produced in } \\
\text { the prose of fuel reforming }\end{array}$ & $\mathbf{6 3}$ & $\mathbf{3 8}$ \\
\hline $\begin{array}{c}\text { The cost of hydrogen produced in } \\
\text { the process of coal gasification }\end{array}$ & $\mathbf{1 0 0}$ & $\mathbf{6 2}$ \\
\hline $\begin{array}{c}\text { The cost of hydrogen produced in } \\
\text { the process of biomass } \\
\text { gasification }\end{array}$ & $\mathbf{1 4 0}$ & $\mathbf{8 0}$ \\
\hline
\end{tabular}

Life of fuel cell, and the electrolyzer is 10 years, remaining service life assumes for 20 years. As the profit is assumed the avoided costs to purchase electricity from electricity system after the unit price 0.56 PLN/kWh a year zero and $0.85 \mathrm{PLN} / \mathrm{kWh}$ in the twentieth year of operation for the variant I, for variant II $1 \mathrm{PLN} / \mathrm{kWh}$ a year zero and 1.3 PLN/kWh in the twentieth year. Economic calculation assumes that additional hydrogen (backup) is produced in the steam reforming process. The analysis does not include the financial gains associated with receiving certificates for the production green energy. According to the authors of power engineering is a branch of industry which should be profitable without support systems. The value of the rate of return was adopted at $8 \%$, while the value of the reinvestment rate at $10 \%$. The results of the economic analysis are in table 2.

Table 2. The results of the economic analysis

\begin{tabular}{|c|c|c|c|c|c|c|}
\hline $\begin{array}{c}\text { \% of investments } \\
\text { costs }\end{array}$ & NPV & MNPV & PI & IRR & MIRR & DPP \\
\hline \multicolumn{7}{|c|}{ Variant I } \\
\hline 100 & -2398 & - & - & - & - & - \\
\hline 50 & -580 & - & - & - & - & - \\
\hline 33 & 25 & 299 & 1.02 & 8.3 & 9.3 & 19 \\
\hline 25 & 328 & 602 & 1.39 & 12.7 & 10.9 & 12.5 \\
\hline \multicolumn{7}{|c|}{ Variant II } \\
\hline- & 797 & 1383 & 1.5 & 14.2 & 11.4 & 10 \\
\hline
\end{tabular}

Performed economic analysis allows for the formulation of the following conclusions:

- power supply energy customer with established profiles: customer energy, wind and sunlight by the hybrid power generation system is an uneconomic (NPV <0). This is due to the high investment costs and low capacity values of the coefficients factor,

- in the event of a reduction of $50 \%$ of the investment project is still unprofitable $(\mathrm{NPV}<0)$,

- the construction and exploitation of the hybrid power generation system generates losses by reducing the total investment by $67 \%$. In this case, the system virtually does not generate profits, because discounted payback time DPP is 19 years,

- construction and maintenance hybrid power generation system would be profitable if investment costs were reduced by $75 \%$, in this case the discounted payback time DPP is 12.5 years,

- in the case of variant II (reduction of investment in relation to variant I about $45 \%$ of the unit and increase electricity prices to value of 1 $\mathrm{PLN} / \mathrm{kWh}$ ) construction and operation of the hybrid power generation system is a viable project and time of return, the DPP is 10 years.

At today's electricity prices, investment costs related to the construction of the hybrid power 
generation system and without certificates for green energy, there is no economic justification. Analyzed hybrid system may be used in situations where the investment is a matter of priority, for example: military applications or pilot installations for research purposes.

\section{References}

1. B. Ceran, K. Sroka, Acta Energetica, 2/23, 36-42 (2015)

2. R. Szczerbowski, B. Ceran, Polityka Energetyczna, 16, 193 - 205 (2013)

3. J. Paska, M. Kłos, Prz Elektrotech, 8, 93, (2010)

4. K. Balachander, S. Kuppusamy, P. Vijayakumar, International Conference on Emerging Trends in Science, Engineering and Technology, 462-466, (2012)

5. B. Ceran, P.A. Bernstein, Poznan University of Technology Academic Journals, 79, 157-163 (2014)

6. C. Wang, M.H. Nehrir, IEEE Transactions, 957-964, (2008)

7. Z. Lubośny, Farmy wiatrowe $w$ systemie elektroenergetycznym (WNT, 2009)

8. P. Bronski, J. Creyts, M. Crowdis, S. Doig, J. Glassmire, L. Guccione, P. Lilienthal, J. Mandel, B. Rader, D. Seif, H. Tocco, H. Touati, The Economics of Load Defection. How Grid-Connected SolarPlusbattery Systems Will Compete With Traditional Electric Service, Why It Matters, And Possible Paths Forward (Rocky Mountain Institute, 2015)

9. D. R. Peterson, P. Zelenay, ElectroHyPEM Workshop (2014)

10. The Fuel Cell and Hydrogen, Annual Review, 4th Energy Wave (2015)

11. T. Riis, E. F. Hagen, P. J. S. Vie, Ø. Ulleberg, (IEA, 2006)

12. Technology Roadmap Hydrogen and Fuel Cells, (IEA, 2015)

13. P. E. Dodds, W. McDowall, UKSHEC Working Paper, 6 (2012)

14. T. Smolinka, M. Thomassen, A. Oyarce, F. Marchal, (JU FCH project in the Seventh Framework Programme, 2016)

15. Renewable Power Generation Costs in 2014, (IEA, 2015)

16. E-storage: Shifting from cost to value wind and solar applications, (WEC, 2016)

17. O. H. Mohammed, Y. Amirat, M. Benbouzid, A. Elbast, IEEE ICGE, 119-123 (2014) <hal01023490>

18. A. A. Elbaset, Journal of Electrical Systems, 7-2, 270-286 (2011)

19. Technology Roadmap, Solar Photovoltaic Energy, (IEA, 2014) 